\title{
Infant Feeding Practices Using Local Flours in Relation to Nutritional Status of Children Aged 6 to 24 Months Surveyed in Maternal and Child Protection Centers of Abidjan (Côte d'Ivoire)
}

\author{
Mandoué Stéphanie Bamba, Grodji Albarin Gbogouri*, Edith Adouko Agbo, \\ Dogoré Yolande Digbeu and Kouakou Brou
}

\section{Department of Food Sciences and Technology, Laboratory of Nutrition and Food Safety, Nangui Abrogoua University, 02 BP 801 Abidjan 02, Côte d'Ivoire}

\begin{abstract}
Objectives: The aim of the study is to evaluate the use of local flours in supplementary feeding for 6 to 24 month old children in relation to their nutritional status in Abidjan.

Methods: A cross-sectional survey was conducted on 480 mother-child couples in twelve maternal and child protection centers located in four municipalities in Abidjan. Questionnaires focused on the economic characteristics of mothers, the frequency of use of local flours, sources of local flours, ingredients used for flour production. The local composite flours mainly consumed by the children were sampled for biochemical analysis.

Results: Our of the 480 mothers, $73 \%$ had an income-generating activity and $27 \%$ had no activity, $10 \%$ of them were students. About $13 \%$ of the mothers with income-generating activities use only local flours, $10 \%$ of them mainly use industrial flours and $50 \%$ alternately use local flours and industrial flours. All mothers used cereals for flour production, $1 \%$ of the mothers used cassava and $98.54 \%$ used soya flour as supplement. The local flour mainly consumed, "Anango baka" with two variants, was unbalanced as far as its nutrient composition is concerned. The nutritional status of the children surveyed showed that stunting was the most widespread form of malnutrition with a prevalence of $17.9 \%$.

Conclusion: The three local composite flours used by the mothers showed a poor nutritional value. A high rate of chronic malnutrition has been reported for 6 to 24 month old children visiting maternal and child protection centers located in Abidjan.
\end{abstract}

Keywords: Complementary feeding, Child nutrition, Malnutrition status, flours.

\section{INTRODUCTION}

Malnutrition causes the death of more than 2.5 million of children per year in the world. It is a factor in more than half of the children who die after the first month of life [1]. Malnutrition remains the major public health problem especially in the developing countries [2]. Today more than $40 \%$ of children in these countries are affected by chronic malnutrition. In many West African countries, demographic and health surveys reveal that a child under three years old is stunted [3]. In Côte d'Ivoire, the nutritional status of children under 5 years of age deteriorated significantly over the last decade [4]. Malnutrition is a public health problem because it contributes directly or indirectly to the high infant and child mortality rate. This rate is estimated to be $33 \%$ in Côte d'Ivoire [5].

From birth to 6 months of age, breast milk covers all the nutritional requirements of the child body [6]. However, from 6 months, breast milk becomes insufficient to cover the entire child's energy and

\footnotetext{
*Address correspondence to this author at the Department of Food Sciences and Technology, Laboratory of Nutrition and Food Safety, Nangui Abrogoua University, 02 BP 801 Abidjan 02, Côte d'Ivoire; Tel: 0022558426714, 0022503384619; E-mail: albaringrodji@yahoo.fr
}

protein needs [7]. This period is known as the weaning period which extends from 6 months to 1 year or 2 years during which, it is necessary to bring new foods to supplement the intake of breast milk. Known as complementary foods, these new foods given to children during the weaning period must bring to them the main protein, fat and carbohydrate nutrients in a balanced- ratio [8-10]. All categories populations used flours (local and industrial) for children's feeding from 6 months. Imported industrial flours are sold in shops with high prices [11]. In African countries generally, during weaning, mothers usually feed their children with traditional flour or mixtures of local flours from cereals and tubers [12]. These traditional flours used are often made with a single raw material, poor in macronutrient and micronutrient. In a previous study, information was provided on the way to improve the nutritional compositions of complementary foods [13]. According to them, the development of a recommended nutritional composition for a complementary food is just one of many factors that can improve infant and young children's nutrition.

The aim of this study is to evaluate dietary practices using local flours for children 6 to 24 months of age in relation to their nutritional status in the maternal and child health centers in four municipalities of Abidjan. 


\section{MATERIALS AND METHODS}

\subsection{Study Framework and Population}

This work is a descriptive cross-sectional study held from September 2015 to January 2016 on 480 motherchild couples in twelve maternal and child protection centers located in four municipalities in Abidjan: Abobo, Treichville, Yopougon and Cocody. These municipalities were chosen because of the wide disparities in cultural, social and economic conditions and the presence of centres for the nutritional care of children.

Sampling was randomly done after explanations of the modalities of the mothers' participation. The mother-child couples were selected according to the following criteria:

- Inclusion criteria: voluntary mothers with at least one healthy child aged 6-24 months present in one of the health centers visited during the survey period.

- Exclusion criteria: refusal of mothers to participate or mothers who are absent or mothers of children aged 6-24 months who are sick or convalescent.

\subsection{Course of the Study}

The study was conducted in two phases. The first consisted of a field survey on the use of local flours in the diet supplement of children from a questionnaire and anthropometric measurements on children. The second part consisted of the selection and the sampling of local composite flours mainly consumed by children in order to determine their biochemical compositions and their energy values.

\subsection{Survey Questionnaire}

The survey of mother-child couples focused on the use of flours in complementary foods for children aged 6 to 24 months. Interviews were conducted using a questionnaire on the economic condition of the mother, sources of local flours, local ingredients used in flours production, and frequency of use. The survey consisted of gathering information through interviews.

\subsection{Anthropometric Parameters Measurements}

The children's nutritional status was assessed from anthropometric parameters such as weight and height. The weight of children was measured using an electronic scale and a baby scale. The children's height was measured to the nearest $\mathrm{mm}$ using a horizontal height gauge (graduated in $\mathrm{cm}$ ). Anthropometric indices such as height / age $(\mathrm{H} / \mathrm{A})$, weight / age $(\mathrm{W} /$ A) and weight / height $(\mathrm{W} / \mathrm{H})$ were used to assess the nutritional status. They were expressed in Z-scores and compared to $\mathrm{WHO}$ standards [14]. Stunting, wasting and underweight were defined as $\mathrm{H} / \mathrm{A}, \mathrm{W} / \mathrm{A}$ and $\mathrm{W} /$ $\mathrm{H}<-2 \mathrm{Z}$-scores respectively. Malnutrition is defined by the presence of at least one of the three types of malnutrition. Children were said to be malnourished if one of the three indices was less than $<-2$ Z-scores. The prevalence of the three types of malnutrition was classified according to the degree of malnutrition (moderate or severe).

\subsection{Selection and Biochemical Characterization of Composite Local Flours}

Local flours purchased by mothers in local markets were selected. These are the flours commonly called "Anango baka" with the "Egg banana" and "Prime" variants. Single flour "Bébé fort" made of local ingredients is offered to mothers in a maternal and infant care centre in the municipality of Cocody. Dry matter, ash, proteins and fibres levels were determined according to standard methods of the Association of Official Analytical Chemists [15]. The lipid content was determined according to the Soxhlet method of the French national organization for standardization [16]. Carbohydrates content was determined by nutrient difference using the following equation:

$\%$ Carbohydrates $=[100-(\%$ Moisture $+\%$ Proteins + $\%$ Lipids $+\%$ Ash $+\%$ Fibres $)]$.

Energy value was calculated with $4 \mathrm{Kcal} / \mathrm{g}$ for carbohydrates, $4 \mathrm{Kcal} / \mathrm{g}$ for proteins and $9 \mathrm{Kcal} / \mathrm{g}$ for lipids according to [17] and expressed on a dry matter basis using the following equation:

Energie value $=(\%$ Proteins $\times 4)+(\%$ Carbohydrates $\times$ $4)+(\%$ Lipids $\times 9)$

\subsection{Statistical Analysis}

A questionnaire was developed using the Sphinx plus $^{2}$ software (le sphinx development, Parc Altais74650 Chavanod-FRANCE), which was designed for surveys, and the data was processed before being transformed into Excel file to plot figures. Anthropometric data were analysed with ENA 2011 (Emergency Nutrition Assessment) software. Results are expressed as mean \pm standard deviation. The 


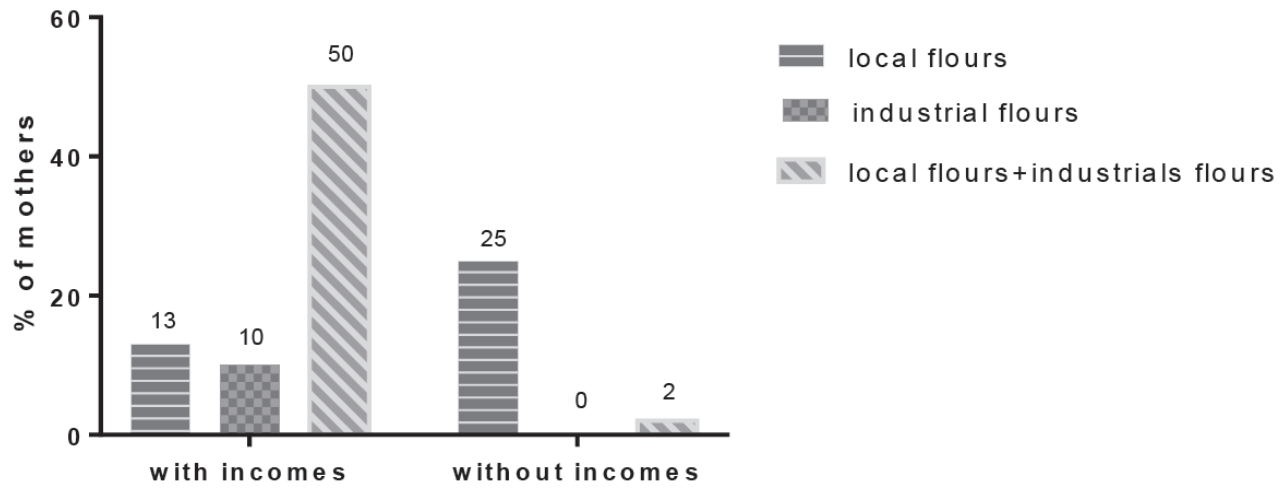

Figure 1: Relation between frequency of use of local flours and mothers economic conditions.

analysis of the results of the biochemical parameters was carried out using the STATISTICA 7.1 software (Statsoft Inc., Tulsa-USA Headquarters). Averages were compared using the Duncan test at the $5 \%$ threshold.

\section{RESULTS}

\subsection{Economic Characteristics of Mothers and Frequency of Use of Local Flours}

Figure 1 shows the economic characteristics of the mothers and the frequency of use of local flours. These results showed that out of 480 mothers, $73 \%$ have an income-generating activity and $27 \%$ have none, $10 \%$ of them are students. About $13 \%$ of mothers with incomegenerating activities use only local flours, $10 \%$ mainly industrial flours, and $50 \%$ alternately use local flours and industrial flours for children's feeding. Among the $27 \%$ of mothers without income-generating activities, $25 \%$ used local flours and only $2 \%$ use industrial flours alternately with local flours.

\subsection{Sources of Flour Supply}

In the four municipalities where the survey was carried out (Abobo, Yopougon, Cocody, Treichville), mothers are largely consumers of simple local flours based on cereals (millet, maize, rice, sorghum) or composite local flours like "Anango baka" and "bébé fort" sold in local markets and in infant health centres respectively. In Abobo and Cocody, mothers get local flours, which are simple or composite mostly in infant health centres (IHC) $(56.53 \%$ and $65.83 \%)$. As for mothers in Yopougon, they get their supplies from merchants in local markets.

In the municipality of Treichville, local flours are produced by mothers in households.

The factorial correspondence analysis of local flour sources (Figure 2) revealed three (3) groups of mothers. The mothers of Treichville form group 1 and those of Abobo and Cocody group 2. Group 3 was constituted by the mothers of Yopougon. Axis 1 of inertia $90.20 \%$ differentiates mothers who produce local flours in households (group 1) from those who obtain them from infant health centres (IHC) (group 2). Axis 2 of inertia $9.80 \%$ reveals the mothers of group 3 who obtain their supplies in local markets.

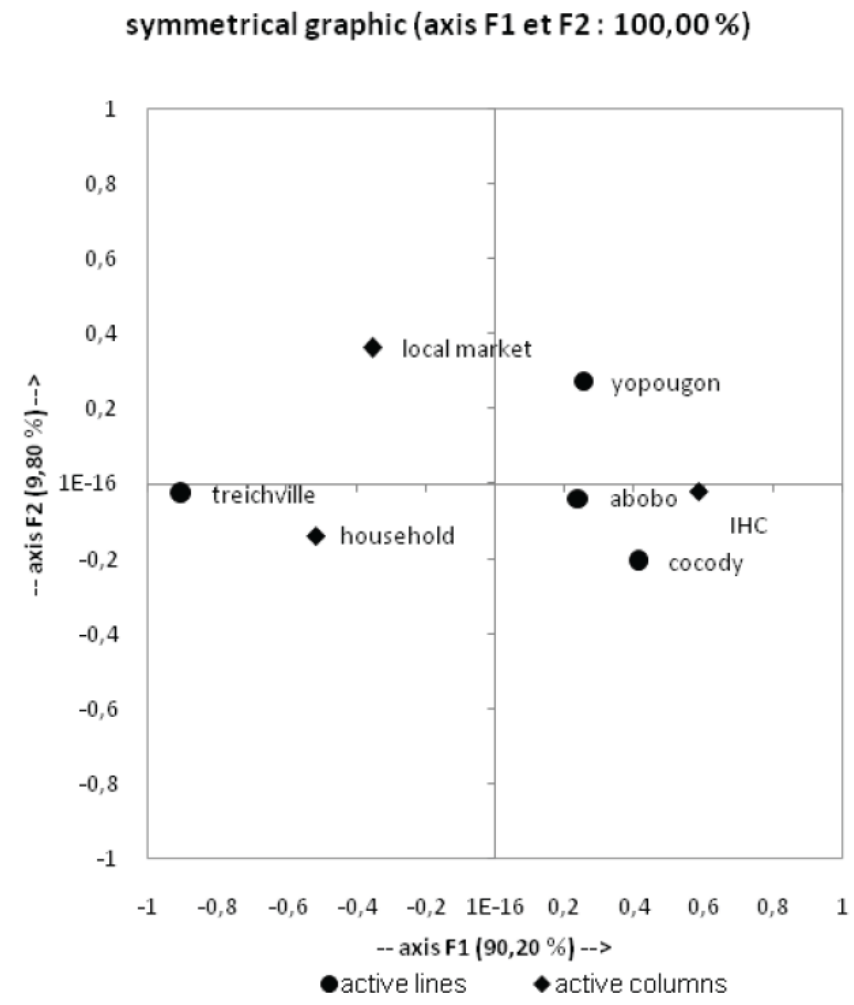

Figure 2: factorial correspondence analysis of sources of local flour used by Abidjan mothers.

\subsection{Local Flours, Raw Materials and Frequency of Use}

Figure 3 shows the frequency of use of raw materials for local flours production. The results showed that mothers commonly use cereal flours (corn, 


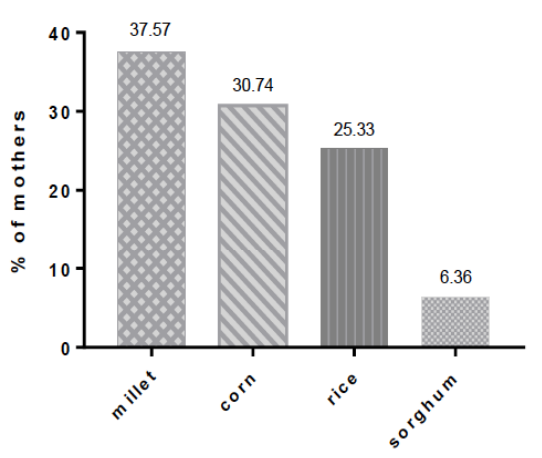

a) Cereals

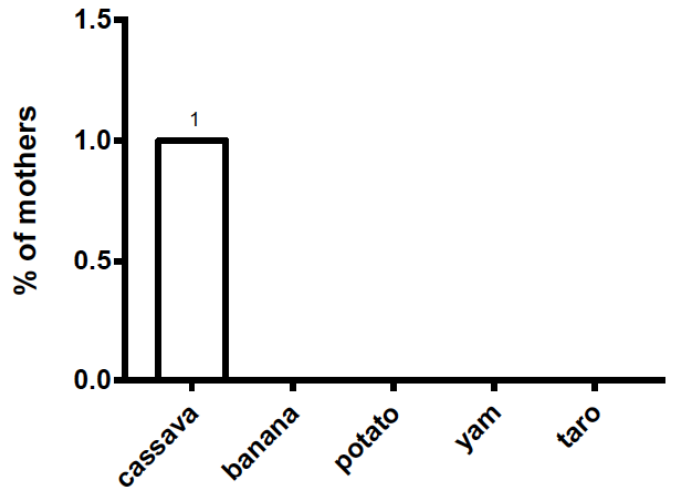

b) Starch

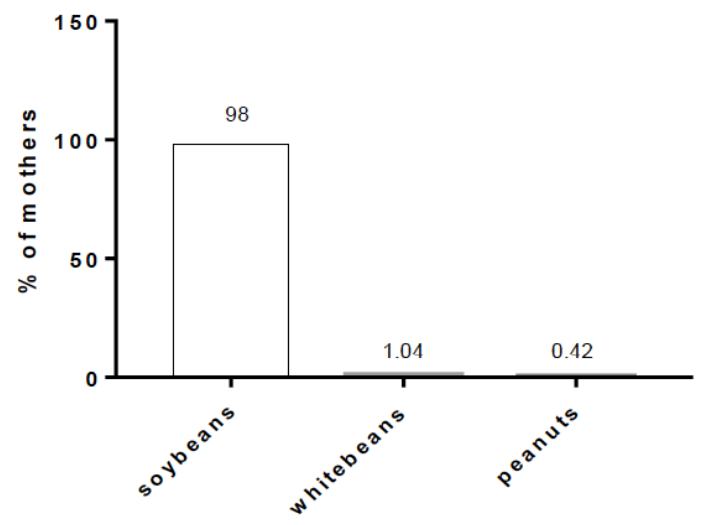

c) Oilseeds

Figure 3: Frequency of use of raw materials for local flour production.

rice, millet, sorghum), starch flour mainly cassava and wheat flour (soybeans, white beans, peanuts). Millet is the cereal most widely used for the production of local flour for supplementary feeding. Millet flour is used by $37.57 \%$ of the mothers. Corn flour is second with $30.74 \%$ of mothers using it. About $25.33 \%$ of mothers use rice flour. Sorghum flour is used by $6.36 \%$ of mothers (Figure 3a). Sorghum is therefore the least used cereal for the supplemental diet of the child. Flour based on starchy foods (cassava, potato, banana, yam, taro) are little known and therefore little used by mothers. Only $1 \%$ of mothers use cassava flour for the preparation of porridge (Figure $\mathbf{3 b}$ ). Oilseeds flours are used as a supplement to cereal flours. Soy flour is the most widely used. It is used by $98.54 \%$ of mothers, white bean and peanut flours are the least used by mothers with the frequency of $1.04 \%$ and $0.42 \%$ respectively (Figure $\mathbf{3 c}$ ).

\subsection{Nutritional Status of Children Surveyed}

Table 1 describes the nutritional status of children in Abobo, Treichville, Yopougon and Cocody. The overall children malnutrition prevalence in the 4 municipalities was about $2.1 \%$ for acute malnutrition with $1.7 \%$ for the moderate form and $0.4 \%$ for the severe one. Stunting prevalence was about $17.9 \%$. Moderate and severe forms were respectively $10.8 \%$ and $7.1 \%$. Underweight prevalence was $6.9 \%$ with $4.8 \%$ for moderate underweight and $2.1 \%$ for severe underweight.

\subsection{Biochemical Composition of Local Composite Flours Used by Mothers}

Table 2 shows the biochemical composition of the local composite flours commonly used by the surveyed mothers. These are the "Anango baka" flour varieties which are constituted by Egg banana and Prime and "Bébé fort" flour. "Bébé fort" flour contains 1.70\% ash, $16.63 \%$ proteins, $10.14 \%$ lipids, $0 \%$ fibre and $65.25 \%$ carbohydrates. Except for fibres, the results showed a significant difference $(p<0.05)$ between all the parameters studied. Ash, protein, fat and energy values are higher in "Bébé fort" compared to the "Anango baka" flours (Prime and Egg banana). Prime has the highest dry matter and Carbohydrates $94.02 \%, 87.98 \%$ content respectively. Results showed that flours do not contain fibres.

\section{DISCUSSION}

This study was conducted in order to show the place of local flours in the feeding practices of children 
Table 1: Nutritional Status of Children Surveyed

\begin{tabular}{|c|c|c|}
\hline Indicator & Effective & Prevalence (\%) \\
\hline \hline Z-score weight for height & $\mathrm{N}=476$ & 8 \\
Moderate acute malnutrition (emaciation) & 2 & 1,7 \\
Severe acute malnutrition (emaciation) & 466 & 9,4 \\
Good nutritional status & $\mathrm{N}=480$ & 10,8 \\
\hline Z-score height for age & 52 & 7,1 \\
Moderate chronic malnutrition (stunting) & 34 & 82,1 \\
Severe chronic malnutrition (stunting) & 394 & $\mathrm{~N}=478$ \\
Good nutritional status & 23 & 10 \\
Z-score weight for age & 445 & 9,8 \\
Moderate underweight & & 93,1 \\
Severe weight loss & & \\
\hline
\end{tabular}

Table 2: Biochemical Composition of Local Composite Flours Commonly Used by the Surveyed Mothers

\begin{tabular}{|c|c|c|c|c|}
\hline Parameters & Egg banana & Prime & Bébé fort $^{\text {Standard flour }^{*}}$ \\
\hline \hline Dry matter (\%) & $91.83 \pm 0.01^{\mathrm{c}}$ & $94.02 \pm 0.00^{\mathrm{a}}$ & $93.72 \pm 0.15^{\mathrm{b}}$ & 95 \\
Ash (\%) & $0.00 \pm 0.00^{\mathrm{c}}$ & $0.20 \pm 0.00^{\mathrm{b}}$ & $1.70 \pm 0.15^{\mathrm{a}}$ & 2,9 \\
Proteins (\%) & $4.38 \pm 0.00^{\mathrm{c}}$ & $5.25 \pm 0.00^{\mathrm{b}}$ & $16.63 \pm 0.00^{\mathrm{a}}$ & 8 \\
Lipids (\%) & $7.49 \pm 0.01^{\mathrm{b}}$ & $0.59 \pm 0.00^{\mathrm{c}}$ & $10.14 \pm 0.00^{\mathrm{a}}$ & 3,8 \\
Fibres (\%) & $0.00 \pm 0,00^{\mathrm{a}}$ & $0.00 \pm 0,00^{\mathrm{a}}$ & $0.00 \pm 0,00^{\mathrm{a}}$ & 68 \\
Carbohydrates (\%) & $80.25 \pm 0.53^{\mathrm{b}}$ & $87.98 \pm 0.00^{\mathrm{a}}$ & $65.25 \pm 0.00^{\mathrm{c}}$ & 400 \\
Energy (Kcal/100g) & $405.93^{\mathrm{b}}$ & $378.19^{\mathrm{c}}$ & $418.78^{\mathrm{a}}$ & \\
\hline
\end{tabular}

"FAO/WHO [18].

The values of the same line followed by different letters show significant differences $(p<0.05)$. Each value is an average of results obtained by 3 tests \pm standard deviation of this average.

aged 6 to 24 months in Abidjan. Out of $27 \%$ of mothers without income-generating activities, $25 \%$ used local flours for supplementary feeding. The high use of local flours to feed children from 6 months could be explained by the availability of local ingredients in the city of Abidjan and their greater accessibility in terms of cost. The surveys showed that cereals are the most widely raw materials used to product local flours. Flours based on starchy foods (cassava, potato, yam, taro) are little used by mothers. These results could be explained by the fact that cereals are important staple foods in traditional systems in Côte d'Ivoire, most of which are used in infant diets [19]. However, the choice of millet, maize, and rice for cereals in the manufacture of local infant meals is linked to the household food habits in Côte d'Ivoire. These results are similar to reports by Brou et al. [20] and Amagloh et al. [21]. According to these authors, in low-income countries, most infants are given cereals-based complementary foods. Cereals processed into dried products and reconstituted as porridge are widely promoted as complementary foods in sub-Saharan Africa by researchers and health organizations [20]. On the other hand, soybean is an ingredient considered as a highly nutritious food that can be used in the care of young children in health centers. In addition, soybeans are highly advised to mothers visiting these health centers for the manufacture of local infant flours. This could explain its widespread use.

Concerning the nutritional status of the children surveyed, the study found that 129 children or $26.9 \%$ were malnourished. The results showed the importance of chronic malnutrition among children aged 6 to 24 months in Abidjan since it affects $17.9 \%$ of them. The use of low-quality complement foods could partly explain the high prevalence of stunting observed in this study. These results were consistent with those found in previous studies [22, 23]. This prevalence of chronic malnutrition was identical to that obtained in urban areas in Northern Côte d'Ivoire (17\%) [24]. This result was similar to those reported by Koné et al. [25] that showed that stunting was the most important prevalence among children from six municipalities of Abidjan district. 
The nutrient composition of the composite flours sold in local markets and that proposed in the maternal and infant care centres of some municipalities showed that, with the exception of "Bébé fort", "Prime" and "Egg banana" have low ash, protein rate and the high content of carbohydrates. These contents are not meet world health organization (WHO) and food and agricultural organisation (FAO) recommended standards for complementary food. Ash content represents the total mineral content in food. The relative low ash content indicates that "Anango baka" flours are poor in minerals. Also, they are poor in proteins and have high contents of carbohydrates. Lipid content is lower than the $\mathrm{WHO}$ and $\mathrm{FAO}$ recommended standards for complementary food. The recommended contents are $2.9 \%$ for ash, $15 \%$ for proteins, $68 \%$ for carbohydrates and $8 \%$ for lipids, according to [18]. In 2008 in sub-Saharan Africa, the World Health Organization recorded more than 8 million children affected by more or less severe protein-energy malnutrition, which can affect their physical and intellectual development and, ultimately, their ability to participate in the development of their country [26]. The high levels of protein, lipid and energy contained in "Bébé fort" could be used to solve the various forms of malnutrition such as protein-energy malnutrition.

\section{CONCLUSION}

The results of this study showed the importance of local flours in the complementary feeding of children from 6 to 24 months in the city of Abidjan. Local flours are used by mothers regardless of their economic characteristics. Simple cereal-based flours are widely used by mothers for the supplementary feeding of children. Starch-based flours are still unknown to mothers. Soybean flour remains the most used in addition to cereal flours. This study noted the scarcity of composite flours made from local products. Analysis of the biochemical composition of the three local composite flours used by the mothers showed a poor nutritional value of these composite flours. A high rate of chronic malnutrition has been reported. In view of these few results, we recommend that studies be carried out on the formulation, diversification and popularization of composite flours made from local ingredients to ensure adequate nutrition during early childhood.

\section{ETHICALS CONSIDERATIONS}

This study has been approved by the National Health and Public Hygiene Ministry (0203/MSHP/DGS/ DFRS/KJM).
In each municipality, health centers authorities were contacted and informed before survey. Free informed consent to participate the survey was obtained from each mother for interview and for taking anthropometric measurements on children.

\section{CONFLICT OF INTEREST}

The authors declare that they have no conflicts of interest.

\section{ACKNOWLEDGEMENTS}

The authors are grateful to the authorities of health districts and hospitals of the city of Abidjan and also to all wise women, mothers who took part in this study.

\section{REFERENCES}

[1] World health organization. Child mortality. PMNCH Fact Sheets 2011; available from http://www.who.int/pmnch/ media/press_materials/fs/fs_mdg4_childmortality/en/.

[2] De Onis M, Frongillo EA, Blössner $M$. Is malnutrition declining? An analysis of changes in levels of child malnutrition since 1980. Bull World Health Organ 2000; 78(10): 1222-33.

[3] Ag BM. Food strategies for improving the nutritional situation in West Africa. 2nd International Workshop; Food based approaches for a healthy nutrition Ouagadougou, Burkina Faso 2003; p. 277

[4] Fond des nations unies pour l'enfance. Analyse de la situation de l'enfant en Côte d'Ivoire, Draft 2014; p. 127.

[5] Fond des nations unies pour l'alimentation. Deuxième conférence internationale sur la nutrition 2014; p. 7.

[6] UNICEF. Breastfeeding: foundation for a healthy future 1999. Available from https://www.unicef.org/publications/files/pub_ brochure en.

[7] Kikafunda JK, Walker AF, Tumwine JK. Weaning foods and practices in central Uganda: a cross-sectional study. AJFAND 2003; 3(2). https://doi.org/10.4314/ajfand.v3i2.19139

[8] Trèche $S$, De Benoist $B$, Bzenbourzid D, Delpeuch $F$ L'alimentation de complément du jeune enfant, Orstom éditions 1994; pp. 39-46.

[9] Mouquet $\mathrm{C}$, Bruyeron $\mathrm{O}$, Trèche $\mathrm{S}$. Les farines infantiles : caractéristiques d'une bonne farine infantile. Bulletin du réseau Technologie et partenariat en Agroalimentaire.Numéro 15, Mai 1998; p. 48.

[10] Mouquet-rivier C. L'alimentation de complément de jeunes enfants au Burkina Faso, journée portes ouvertes du «CIRD», centre IRD de Ouagadougou. Présentation de power point, 27 Avril 2006; pp. 1-59.

[11] Zannou Tchoko J, Bouaffou KG, Kouame KG, Konan BA Étude de la valeur nutritive de farines infantiles à base de manioc et de soja pour enfant en âge de sevrage. Bulletin de la Société Royale des Sciences de Liège 2011; 80: 748-58.

[12] Briend A. Prévention et traitement de la malnutrition, Guide pratique. Institut Français de recherche Scientifique pour le Développement en Coopération Edition de l'Orstom 2003; p. 67.

[13] Lutter CK, Dewey KG. Proposed nutrient composition for fortified complementary foods. J Nutr 2003; 133(9): 3011S$20 \mathrm{~s}$.

https://doi.org/10.1093/jn/133.9.3011S 
[14] Organisation mondiale de la santé. Normes de croissance OMS et identification de la malnutrition aigüe sévère chez l'enfant: déclaration commune de l'organisation mondiale de la santé et du fond des nations unies pour l'enfance 2009 ; 11p. Disponible sur http://www.who.int/nutrition/publications/ severemalnutrition/9789241598163/en/.

[15] AOAC. Official methods of analysis, $15^{\text {th }}$ Edn. Association of Official Analytical Chemists, 1990; p. 774

[16] AFNOR. Recueil de normes françaises, corps gras, graines oléagineuses, produits dérivés, 1986; p. 527

[17] Livesey G. Metabolizable energy of macronutrients. Am J Clin Nutr 1995; 62(5 Suppl): 1135S-42S. https://doi.org/10.1093/ajen/62.5.1135S

[18] FAO/WHO. Programme mixte FAO/WHO sur les normes alimentaires. Rapport des vingt-septième sessions du comité du codex sur la nutrition et les aliments diététiques ou de régime ALINORM 06/29/26 2006; p. 105.

[19] Brou K, Kouadio NJPE, Due AE, Kouamé KS, Tano K, Dago G. Effects of processing method and blend on some physicochemical properties and digestibility of flours made from selected cereals and legumes. Int $\mathrm{J}$ Biol Chem Sci 2009; 3(5): 1151-60.

[20] Amagloh FK, Hardacre A, Mutukumira AN, Weber JL, Brough L, Coad J. Sweet potato-based complementary food for infants in low income countries. Food Nutr Bull 2012; 33(1): 3-10. https://doi.org/10.1177/156482651203300101
[21] Sanoussi AF, Dansi A, Bokossa-yaou I, Dansi M, Egounlety M, Sanni LO, Sanni A. Formulation and biochemica characterization of sweet potato (Ipomoea batatas) based infant flours fortified with soybeanand sorghum flours. Int $\mathrm{J}$ Curr Microbiol App Sci 2013; 2(7): 22-34.

[22] Amoussa-Hounkpatin W. Évaluation du potentiel de couverture des besoins en vitamines $A$ des jeunes enfants à partir des sauces accompagnant les aliments de base consommés au Bénin. Thèse de Doctorat de I'Université Montpellier 2, France 2011; p. 261

[23] Zannou Tchoko J, Bouaffou KG, Kouame KG, Konan BA Étude de la valeur nutritive de farines infantiles à base de manioc et de soja pour enfant en âge de sevrage. Bulletin de la Société Royale des Sciences de Liège 2011; 80: 748-58.

[24] Aké-Tano O, Tiembré I, Konan EY, Donnen P, Dagnan NS, Koffi K, Dramaix M. Malnutrition chronique chez les enfants de moins de 5 ans au nord de la Côte d'Ivoire, Santé Publique 2010; 22(2): 213-20. https://doi.org/10.3917/spub.102.0213

[25] Koné MB, Traoré S, Brou K, Agbo AE, Gnakri D. Assessment of Serum Calcium, Serum Iron and Nutritional Status among Under-Five Children in Six Municipalities of Abidjan District Côte d'Ivoire. Int J Child Health Nutri 2014; 3: 139-147. https://doi.org/10.6000/1929-4247.2014.03.03.4

[26] Ilboudo N. Les déterminants de la malnutrition des enfants au Burkina Faso. Mémoire de Master, Institut de recherche empirique en économie politique 2004; p. 79.

Received on 20-04-2018

Accepted on 11-07-2018

Published on 14-09-2018

https://doi.org/10.6000/1929-4247.2018.07.03.2

(C) 2018 Bamba et al.; Licensee Lifescience Global.

This is an open access article licensed under the terms of the Creative Commons Attribution Non-Commercial License (http://creativecommons.org/licenses/by-nc/3.0/) which permits unrestricted, non-commercial use, distribution and reproduction in any medium, provided the work is properly cited. 